\title{
Legal liability arising from the disclosure of the secrets of the investigation into Iraqi law
}

\author{
Dr.khaliedMohamadAjaj \\ Faculty of Law/ Cihan University / Sulaymaniyah
}

\begin{abstract}
The obligation to investigate the secrets of the duty imposed by law as well as the ethics law makes it compulsory law, The range of certain people maintain that the secrets of the investigation to reach them during the exercise of their work, or as many of them news and information. As the legislator, it sought from behind the protection and preservation of the public interest, as well as self-interest of individuals, based on the law to keep these secrets in the legal texts, according to which the existing investigation to maintain secrets and not be disclosed, but there are exceptions may be contained on a password may be from during which exists to reveal them without confirming penal responsibility, as is the case in some crimes, crimes the security of the country's internal or external. This research deals with the discussion of the problem of disclosure of the secrets of the investigation and the consequent liability in the theoretical framework. It concludes with the research findings and relevant recommendations.
\end{abstract}

Keywords: disclosure, the legislator, investigation, violating, responsibility, moral duties, divulging, text, publish.

\section{INTRODUCTION}

The concealment of secrets and the criminalization of disclosure of moral duties, but is one of the most important requirements of the principles of honor and honesty. On the basis that the laws and regulations has been necessitated to maintain the secrets and the criminalization of disclosure for several reasons, the most important to protect the public interest and maintenance in the community, and the protection of the owners of secrets and their status and their position in order to prevent endangering the reputation of the professions of lack of confidence, respect, and that gives owners of high trust and respect from the public. One of these professions and the judiciary investigation, law, and other functions. Did not find the victim or his family judge or investigator lulled him and deposited his secret, or the accused did not find a lawyer to reassure him and Speak openlymystery, this will touch the human rights and harming the interests of the community college. So punishment report on some denominations appoint if Disclosed up to her knowledge of the secrets through the practice of the profession and the criminalization of disclosure of secrets It is these communities that specializes in the investigation. We can say that the bulk of global legislation has promised to do divulge the secrets of offenses against honor and consideration and the effect it has identified its actions and sanctions, and these laws the Iraqi Penal Code, as stipulated by the sanctions and in articles (437-438). The importance of research to clarify and discuss the legal texts to preserve the ability of the human right to preserve the secrets own, and arranged from a legal responsibility on those who disclose these secrets, since there are a lot of considerations, including those related to the public interest of the community and the interests of individuals, including those related to service justice incurring divulging secrets exposed secrets of the owners of this critical investigation, as well as the possibility of exposure to risk.

\section{THE LEGAL IMPLICATIONS OF DIVULGING SECRETS INVESTIGATION}

As a result of taking confidential at the primary stage of the investigation to the public, it is incumbent on those in charge of the preliminary investigation, whether the investigating judge or prosecutor not to divulge his news outside the scope of their work, as well as in the trial stage, 
whether the court decides its consideration in secret, or in cases where required by law its consideration of the court in secret, it is an obligation on the court guards as things which have been secret trial.There is no doubt that the strength of the legal obligation of guards as the secrets of the investigation, taking into account the rights of the defense, both in the primary stage of the investigation or at the trial stage depends on the protection established by the legislature under the text and without which it becomes the obligation discreet false slogan of no value.

\subsection{The investigation stage}

The confidentiality of preliminary investigation requires that prohibits the publication to tell him that the mere disclosure of some information on investigations is a breach of the duty of confidentiality which is adhered to by all of the connection with the investigation. The focus of the investigation, which prohibits News published the minutes of the investigation, including witness testimony and the report of the interrogation of the accused and expert reports (Hamzawy. A, 1958:435).

A side of Jurists believes that he must be punished for violating the gag order to have the ban limited to the dissemination of news forbidden or incorrect information is not right that the criminal investigation procedures by virtue of confidentiality law who are not adversaries in, and sees that public opinion share does not deny the course of the investigation control, including his right to the functioning of government tool control, so it is more appropriate that the broadcast prosecutors to press reports periodically on the progress of the investigation into the important issues of concern to the public and can interrogator that is shaped in such a manner detrimental to the interests of the investigation and full at the same time desire of the public to follow News of these issues and believes that the text of Article (193) Egyptian sanctions useless (Mostafa. M, 1988:54).

\subsection{Fallout from the disclosure of the secrets of the investigation at the trial stage}

As for the protection of confidential at the trial stage, article 189 of the Egyptian Penal Code, he (punishable ...... whoever posted in one of the advanced ways Zla.ma been in civil suits or criminal courts that have decided to be heard in secret session ... not just on punishment post a complaint or a mere publication of the judgment).Secret session not require radio what had happened at the meeting by way of publishing not only publish the complaint or provision allows, it's because they either publish the complaint made by the court's decision by making a secret meeting, there is no contradiction between the deployed and the court's decision by making a secret session. But the publication of the judgment because the verdicts are issued publicly, even if the trial were held in secret.But at the trial stage it was Iraqi legislator stipulates in Article 236 of the Penal Code that (punishable by imprisonment ..... the publication of one of the ways of publicity.1-news on the trial of the law decided to confidentiality or prevented the court published an investigation or existed in a felony or a misdemeanor or a document of this investigation if the investigating authority had banned radio something from him.

2-news about investigations or proceedings in lawsuits ratios or marital Divorce abandonment or adultery or differentiate.

3-deliberations of the courts.

4-What happened in the public meetings of the courts without honesty and malevolently.

5-publication of the names or pictures of victims of rape and assault on supply and photo the names of juveniles accused of crimes.

6-what happened in the civil or criminal courts that have decided to be heard in closed session or what happened in the investigations ... ...not just punishment for publication of the judgment if the permission of the competent court).

We have previously said that the publicity of the core criminal trials means that the assets of the right of everyone to be taking place without hindrance in accordance with Article 152 of the Criminal Procedure Code deals with publicity calling on the outskirts of the criminal case, witnesses and issuing decisive arbiter in the case. But the publicity does not deal with the deliberations of the judges Deliberation secret courts and prohibits disclosure, Deliberation The last stage in the proceedings in an exchange of opinion and the facts of the case in order to take a break in the decision, and the debate must be a secret confined to the judges of the lawsuit. Lay judge may not disclose what happened to 
them. (AbdulSattar. F, 1985: 102).It is stipulated by the Iraqi legislature in Article (236/3) of the Iraqi Penal Code, saying (punishable by imprisonment for a term not exceeding two years or a fine not exceeding two hundred dinars, or either of the deployment of one of the ways of publicity ... .. 3deliberations...... Courts). This offense Iraqi legislator in Article (188/4) and the offenses for urgent external security of the state and the mind of defense secrets as stipulated he (is secretly defense secrets .......).

\section{Liability for disclosure of the secrets of the investigation}

Article (437) of the Penal Code, he It is clear from this article that it was considered a crime to disclose the secrets of misdemeanors under which discloses a secret penalty of not more than imprisonment for two years and fined not less than fifty-one thousand dinars and not more than two hundred and fifty thousand dinars. But Iraqi legislator stressed punishment when committed by an employee or user in the mail, telegraph and telephone services. Punishment also stressed the employee in the case of disclosure of functional information if they harm the interests of the state, as Article 327 of the Iraqi Penal Code, he ((shall be punished by imprisonment for not more than three years and a fine not exceeding three hundred dinars)). ((Each employee or assigned to public service divulges something came to his knowledge by virtue of his job to someone who knows and should not be informed of it. The punishment shall be imprisonment if such disclosure is to the detriment of the interests of the country and shall be punished with the same both been linked with the government's intent to contract or work ...)).

\subsection{Civil responsibility}

The general principle imposed on the people in the community and in accordance with civil law causes of non-compliance obligations, or disrupt the establishment of civil liability, as the person who commits an error damaging to others, whether that damage arising from a breach of a contractual obligation fundamental ways responsibility Streptococcus, or arising for breach of a legal obligation in two fundamental ways tort responsibility.(Al-Nouri, , 1974: 34)

\subsection{Disciplinary responsibility}

Located discloses the secret of the profession as well as a disciplinary sanction as a result of its failure to maintain trade secrets and breach of job duties. (Salama . A, 1988:434)In Iraq, the discipline of state employees and No. Socialist Sector Law Systems (14) of 1991, the general provisions of the discipline in the Job Field With respect to the disclosure of functional secrets was the seventh paragraph of Article IV of the law stipulates that he ((the employee is committed to the following duties: confidentiality of information and documents seen it by virtue of his or during if the confidential nature or the fear of disclosure damaging the state or persons or issued by the orders of his superiors in concealment this remains to be valid even after the termination of his service, and shall be kept official documents secret after being retired or termination of his service in any way)) This is an exception to the originally required by the public interest can not be to get rid of an employee who discloses the secret of disciplinary accountability by leaving Position either resign or retirement or any other reason, and as stipulated in Article 22 of the discipline of state employees the law "does not prevent the end of the service employee for any reason, or loaned or transferred, from accountability under the provisions of this law. " Finally, the legislator has stressed the principle of banking secrecy issuance of the temporary law for securities markets issued Order No. 74 of 2004, as stated in Article (13) thereof that he (the mediator must abide by doing the following: (a) the protection of confidential information belonging to investors only If the need arises for disclosure in accordance with law. (Almizanee. M, 2003:150)

\section{CONCLUSION}

Password that fact or recipe restricted the scope of science is limited in the number of people, if there was a legitimate person or more interest in science is still confined in that range.

The cases of permissibility of this crime can be divided into cases must Secretary toDisclose the secret, but was punished criminally, and may be cases in which the Secretary-General to disclose the secret, and thus the matter is due to his personal, as well as satisfaction if the owner password or 
licensed disclosure.offense conducive secrets of intentional crimes that take the mental elementImage of criminal intent, and therefore not criminally responsible Secretary who neglects gives up papersContaining secret for one of its clients, Briefs by others. The disclosure of the secret is in itself of nefarious acts that do not need to be the intention of damaging because the law does not punished for divulging the secret blatant, but all disclosure because the news by its very nature is not considered a secret from an objective point only if such disclosure of damaging his neighbor physically or literary and finally say that the development of punishment and text criminalizes the disclosure of secrets a crime is only the desire to preserve the public interest does not protect the owner and user passwords.

\section{REFERENCES:}

[1] Abdul Sattar. Fawzia (1985). explaining the Code of Criminal Procedure, Arab Renaissance Publishing House, Cairo.

[2] Almizanee. Khalil Yousef gendyAlmizanee (2003). criminal liability arising from the attack on bank secrecy comparative study, Master Thesis, Faculty of Law, University of Mosul.

[3] Al-Nouri. Hussein (1974). the secret of the banking profession in Egyptian law and comparative law, Union of Arab Banks, 2nd Floor, Beirut.

[4] Hamzawy. Ahmed Osman (1958). Encyclopedia comments on materials Code of Criminal Procedure, Dar Arab renaissance, Cairo.

[5] Mostafa. Mahmoud Mahmoud (1988). the confidentiality of criminal investigations and the rights of the defense, Egypt.

[6] Salama . Ahmed Kamel. (1988). criminal protection for the secrets of the profession, Arab Renaissance Publishing House, Cairo. 